\title{
Membrane-translocating Peptides and Toxins: from Nature to Bedside
}

\author{
Gandhi Rádis-Baptista, ${ }^{*, a}$ Alexandre Kerkis, ${ }^{b}$ Álvaro Rossan Prieto-Silva, ${ }^{c}$ \\ Mirian Akemi Furuie Hayashi, ${ }^{d, e}$ Irina Kerkis ${ }^{f}$ and Tetsuo Yamane ${ }^{*, g, h}$
}

${ }^{a}$ Departamento de Bioquímica, CCB, Universidade Federal de Pernambuco, Recife-PE, Brazil

${ }^{b}$ Clínica e Centro de Pesquisa em Reprodução Humana “Roger Abdelmassih”, São Paulo-SP, Brazil

${ }^{c}$ Laboratório de Herpetologia, Instituto Butantan, São Paulo-SP, Brazil

${ }^{d}$ Departamento de Farmacologia, Universidade Federal de São Paulo, São Paulo-SP, Brazil

${ }^{e}$ Centro de Toxinologia Aplicada (CAT-CEPID), Instituto Butantan, São Paulo-SP, Brazil

${ }^{f}$ Laboratório de Genética, Instituto Butantan, São Paulo-SP, Brazil

${ }^{g}$ Centro de Biotecnologia da Amazônia, Manaus-AM, Brazil

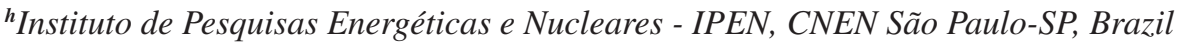

\begin{abstract}
Atualmente, diferentes classes funcionais de peptídeos e toxinas biologicamente ativas isolados de diversos organismos são conhecidas. Em medicina, esses polipeptídios podem ser diretamente utilizados ou podem servir como modelos para a geração de moléculas derivadas. Aqui, nós fazemos referência a três classes de peptídeos e toxinas que agem sobre membranas celulares ou sobre sistemas de transporte por membranas: (i) toxinas binárias; (ii) peptídeos antimicrobianos; (iii) peptídeos penetradores de células. As toxinas binárias têm sido geneticamente manipuladas para gerar imunotoxinas específicas, enquanto os peptídeos antimicrobianos são usados como agentes alternativos contra células tumorais e microbianas resistentes. Os peptídeos penetradores de células têm aplicações que vão desde a transfecção celular quanto ao transporte intracelular de nanopartículas. Nosso grupo vem investigando a capacidade da crotamina, um peptídeo do veneno de cascavel, em translocar membranas celulares, bem como de utilizar a crotamina como sistema de transporte molecular e de análise de imagens.
\end{abstract}

Today, different functional classes of bioactive peptides and toxins isolated from diverse sources of living organisms are known. In medicine, these polypeptides present the potential to be used structurally unmodified or to serve as templates for molecular design of improved derivatives. Here, we refer to members of three classes of remarkable peptides and toxins that act at the cell membranes level and membrane trafficking systems: (i) the binary toxins (ii) the antimicrobial peptides and (iii) the cell penetrating peptides. Binary toxins have been genetically manipulated to generate specific immunotoxins, while antimicrobial peptides are in use as alternative agents against resistant microbes and tumor cells. Cell penetrating peptides have applications as diverse as cell transfection and transport of nanomaterials. Our group is dissecting the capacity of crotamine, a peptide from rattlesnake venom, to translocate cell membranes and use it as a delivery system in the transducing technology and molecular imaging.

Keywords: cytolysin, binary toxin, antimicrobial peptide, cell-penetrating peptide, animal toxin, nanobiotechnology

\section{Binary Bacterial Toxins}

A wide variety of bacterial toxins that has the cell membrane as a target is presently known. Indeed the

*e-mail: radisbra@ufpe.br; tetsuo@usp.br molecular diversity of bacterial toxins is so remarkable that a large number of microorganisms secret several toxic peptides and polypeptides devoid of or having catalytic activity. All these toxins are capable of intoxicating eucaryotic cells by interfering directly with cytoplasmic membrane or by using membrane systems to gain access 
to the interior of cells for the delivery of their active domain.

In the first case, single chain proteins or composed of two separate water-soluble proteins - which oligomerize during their action on phospholipid membrane and form pores or channels - encompass the cytolytic toxins of bacteria. They are produced by microorganims such as Aeromonas hydrophila, Streptococcus pyrogenesis and Staphylococcus aureus, as well as by some animals. In contrast, toxins produced by strains of enterobacteria (Pseudomonas, Shigella, Vibrio cholerae), endosporeforming bacteria (Clostridium and Bacillus), and even plants (Ricinus and Abrus), have a 'B' (receptor binding) moiety and an 'A' (enzymatic active) domain, and constitute the binary classes of toxic polypeptides that translocate membrane systems. Both groups of membrane-active polypeptides - pore-forming and enzymatically active binary toxins - will be examined.

The 'pore-forming toxins, PFTs' are not true translocators, but since they perforate eucaryotic cell membrane in multiple points, the internalization of peptide molecules through the formed pore sometimes occurs - the reason why they are considered here. According to the structure of their domains, they use two mechanisms to form pores (or channels) in the cell membrane: by insertion of amphipathic $\alpha$-helices or insertion of amphipathic $\beta$-hairpins which organize in a $\beta$-barrel structure. For example, the Staphylococcus $\delta$-hemolysins ( $\delta$-toxins), that belong to the class of the $\alpha$-PFTs, when concentrate in high densities on cell surface, associate in bundles of 6 to 8 antiparallel amphipathic $\alpha$-helices that self insert into the membrane and form a hydrophobic channel. On the other hand, toxin protein rich in $\beta$-sheets, $\beta$-PFTs, exemplified by Clostridium perfringolysin, Staphylococcus $\alpha$-toxin, streptolysin O, and aerolysin, bind to cell receptors (e.g. cholesterol, gangliosides and GPI-anchored proteins), oligomerize and one or two $\beta$-hairpins of individual monomers associate. This association on lipid microdomains on cell membranes creates large (250 to $300 \AA$, with $\sim 30$ monomeric units, e.g. perfringolysin and streptolysin $\mathrm{O}$ ) or small pores ( 15 to $30 \AA$, heptameric oligomer, e.g. $\alpha$-toxin and aerolysin), that are the result of the insertion of $\beta$-barrel structures into the lipid bilayer. ${ }^{1}$ Aerolysin, the preformed two-component cytolysin from culture supernatants of Aeromonas hydrophila, is constituted by four domains ( 1 to 4 ) that oligomeryze in a heptameric form on cell membrane after activation by endoproteases (trypsin or $\alpha$-chymotrypsin). Domains 1 and 2 recognize the receptor (GPI-anchored proteins), which are localized in lipid rafts, while domain 3 (and also domain 2) is responsible for oligomerization. Domain 4 inserts into the membrane and forms the channel or pore. Like other pore forming toxins, aerolysin is devoid of enzymatic activity.

Another interesting bacterial pore-forming toxin is streptolysin, secreted by Streptococcus pyrogenesis. Streptolysin is a cholesterol-dependent cytolysin that use cholesterol as receptor in membrane microdomains (lipid rafts) for local toxin concentration before pore formation. In addition to forming pore, streptolysin can translocate a NAD:glycohydrolase into the cytoplasm of target eucaryotic cell. This fact makes streptolysin unique among the PTFs, since it is a first indication of evolutionary adaptation of a pore-forming toxin capable of mediating protein transport. ${ }^{1}$

Bacterial cytolysins formed by two separate hydrophilic proteins, which oligomerize during binding to membrane microdomains ("lipid raft"), is produced exclusively by strains of staphylococcus bacteria. Six toxic protein are secreted by Staphylococcus aureus, namely $\alpha$-hemolysin (Hla), $\beta$-hemolysin (Hlb), $\gamma$-hemolysin (Hlg), $\delta$-hemolysin ( $\delta$-toxin), leukocidin (Luk), and Panto-Valentine leukocidin (PVL). Only Hlg, Luk, and PVL are two-component and hetero-heptameric pore forming cytolytic toxins. ${ }^{2}$ Leukocidins are cytolytic to leucocytes, while $\gamma$-hemolysin lyses human erythrocytes.

Cytotoxic peptides that damage cell membranes by pore formation (cytolysin) can also be purified from the toxic secretion of animals: melittin is isolated from the venom of honeybee, Apis mellifera; ectatomin, from the venom of Ectatomina tuberculatum ants; equinatoxin, from the sea anemona Actina equina.

Mellitin (APEPEPAPEPEAEADAEADPEAGIGA VLKVLTTGLPALISWIKRKRQQG), like $\delta$-toxin ( $\delta$-hemolysin), is a peptide constituted of segments of alternating residues of polar and apolar aminoacids, creating amphipatic $\alpha$-helix structures that permit the toxin to self-associate in solution or in membrane. Amphipatic $\alpha$-helices proved to be the minimal requirements for the hemolytic effect of these peptides. At low concentration, monomeric peptides are structureless in solution, but acquire a $\alpha$-helical structure in lipid membranes. At high concentration, high ionic strenght, or $\mathrm{pH}$, the oligomeric $\alpha$-helical form of peptides is stabilized. ${ }^{3}$ Melittin is cytotoxic to most of eucaryotic cells, but, unlike $\delta$-toxin, mellitin shows antimicrobial activity. The mechanism of melittin-induced pore formation is evidenced by the membrane thinning effect, conducted by two transitional binding states in lipid bilayer: the surface state $(\mathrm{S})$ and the pore-forming state (I). ${ }^{4}$

The ant cytolysin ectatomin is composed by two highly homologous amphiphilic polypeptide chains (37 and 34 amino acid residues) connected by a disulfide bond 
between Cys22 of A chain and Cys20 of B chain. Each chain comprises two anti-parallel $\alpha$-helices linked by a hinge region of four amino acid residues and a disulfide bridge (A) Cys12-Cys34 (B) Cys10-Cys32. Ectatomin is responsible for the major toxic effect of the venom in both mammals and insects. Immunochemical analysis of the intracellular distribution of ectatomin showed that the toxin gets efficiently inserted into the plasma membrane at a concentration of $5 \times 10^{-7} \mathrm{~mol} \mathrm{~L}^{-1}$ and does not penetrate inside the cell. ${ }^{5}$ Two molecules of ectatomin form each pore.

Equinatoxin is another example of cytolysin, but produced by cnidarians (sea anemona, Cnidaria). Equinatoxin, from Actinia equina, belong to the class of actinoporins, the most numerous and most studied cytolisins isolated from several genera of the family Actiniidae and Stichodactylidae. They comprise $20 \mathrm{kDa}$ basic proteins that create pores of $2 \mathrm{~nm}$ in eucaryotic and model lipid membranes by the self-association of four monomers. Actniporins are single chain strucutres dominated by $\beta$-sheet, in which an amphipathic $\alpha$-helix, a tryptophan-rich stretch, and a RGD-motif are embedded. The flexible $\mathrm{N}$-terminal region and a stable beta-sandwich are pre-requisite for proper pore (channel) formation by members of the actinoporin family. ${ }^{6}$ In fact, more than 32 species of sea anemones have been reported to produce lethal cytolytic peptides and proteins. These all cytolysins have been classified into four polypeptide groups, based on their primary structures and functional properties. Group I consists of 5-8 kDa peptides, represented by those from the sea anemones Tealia felina and Radianthus macrodactylus. These peptides form pores in phosphatidylcholine containing membranes. In group II, in addition to equinatoxins, sticholysins and magnificalysins produced by Stichodactyla helianthus, and Heteractis magnifica, respectively, associate typically with sphingomyelin containing membranes and create cation-selective pores. Group III is formed by lethal 30 to $40 \mathrm{kDa}$ cytolytic phospholipases $\mathrm{A}_{2}$ from Aiptasia pallida (family Aiptasiidae) and a similar cytolysin, which is devoid of enzymatic activity, from Urticina piscivora. A thiolactivated cytolysin, metridiolysin, with a mass of $80 \mathrm{kDa}$ from Metridium senile (family Metridiidae) is a single representative of the fourth family. Its activity is inhibited by cholesterol or phosphatides. ${ }^{7}$

Thus far, mellitin, equinatoxin and $\delta$-toxin are prototypes of single chain and single domain cytolysins that cause cell lysis by pore fomation after self association on lipid membranes, whereas aerolysin and streptolysin are representatives of single chain and multi-domain toxins that, after binding to a lipid receptor on target cells, oligomerize and make a pore or channel on membrane. Streptolysin is unique among the pore-forming toxins, since it is the first example of bacterial cytolysin able to translocate an enzymatic domain. The staphylococcal pore-forming toxins $\gamma$-hemolysin, leukocidin, and Panto-Valentine leukocidin are exclusive examples of two separate hydrophilic proteins that initially oligomerize, before association and pore formation. A detailed figure of these bacterial and animal cytolysins can be seen elsewhere. ${ }^{1,7,8}$

Differing from preformed or not associated in solution two-component (mostly non-enzymatic) cytolysins, which cause cell lysis after oligomerization and pore formation, there are numerous binary enzymatically active toxins secreted by bacteria. These are known as 'bacterial binary toxins' and they have essentially one catalytic domain or chain ('A' moiety) and one receptor binding component ('B' moiety) that is single chain or multimeric. Thus, these toxins bind to cell receptor as a preformed 'A-B' binary complex or as a ' $\mathrm{B}$ ' monomers that is subjected to subsequent oligomerization and association of the catalytic 'A' protein component. Examples of bacterial toxins secreted as preformed dimeric or multimeric proteins, with catalytic activity, include botulinum neurotoxins A-G (secreted by Clostridium botulinum), toxin A and B (from C. difficile), $\alpha$-toxin ( $C$. novyi), hemorrhagic and lethal toxins $(C$. sordelli), tetanus neurotoxin (C. tetani), Diphteria toxin (Corynebacterium diphteria); exotoxin A (Pseudomonas aeruginosa), pertussis toxin (Bordetella pertussis), heatlabile enterotoxin (Escherichia coli), shiga and shiga-like toxins (Sighela and other Enterobacteriaceae), and Cholera toxin (Vibrio cholerae). ${ }^{9}$ In Figure 1, the tridimensional structures of bacterial toxins are presented.

These bacterial binary toxins bind to their respective receptor on eucaryotic cell membrane, like the heparinbinding EGF-like growth factor receptor (diphteria toxin), $\alpha 2$-macroglobulin receptor (pertussis exotoxin A), glycolipid Gb3 (Shiga toxin), and ganglioside GM1 (Cholera toxin). Thereafter, the toxin internalization proceeds by receptor-mediated endocytosis, in which the proteins clathrin or caveolin participate, and by transportation from the early endosome to the Golgi apparatus and to the endoplasmic reticulum (ER). For instance, diphteria and shiga toxins, complexed with their receptors, enter cells via plasma membrane-derived vesicles coated with the protein clathrin (clathrin-coated surface pits). Cholera toxin, on the other hand, can alternatively enter into the cells by clathrin-independent endocytic pathway, through the formation of caveolae-cholesterol dependent structures associated to caveolin. ${ }^{10-12}$ Independent of the endocytic carrier for internalization - clathrin or caveolin -, bacterial preformed toxins are initially delivered to early endosome, and then to the cytosol chiefly by two ways: $(i)$ by making 

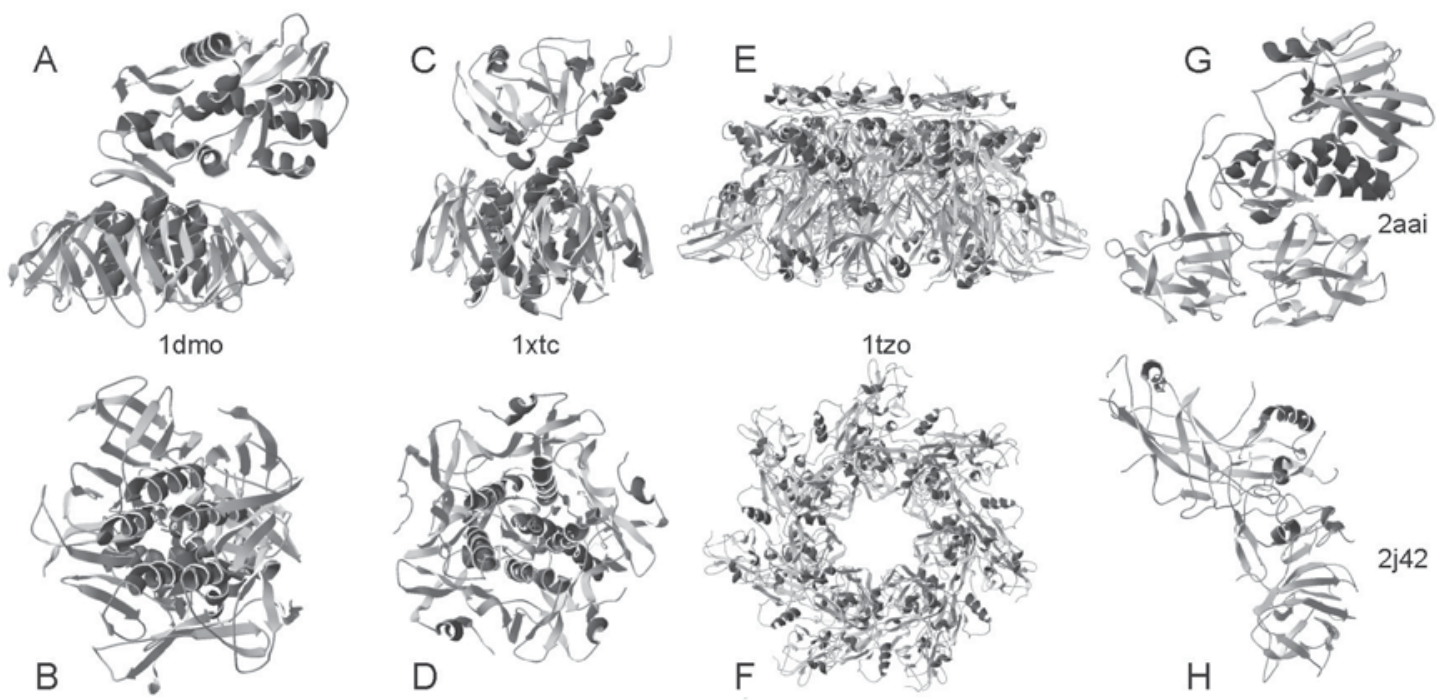

Figure 1. Tridimensional structures of membrane translocating binary toxins. Preformed binary toxins: Shigela toxin (pdb 1dmo), Cholera toxin (pdb 1xtc), and Ricin, from Ricinus communis (pdb 2aai). In-receptor formed binary toxins: Lethal toxin, from Bacillus anthracis (pdb, 1tzo), and C2 toxin, from Clostridium botulinum (pdb 2j42). All $\beta$-sheets are represented in light gray, while $\alpha$-helices are in dark gray. In A it is shown the lateral view of Shigela toxin (1dmo), with its visible receptor binding domain and catalytic domain, while in B is highlighted the pentameric binding domain. In $\mathrm{C}$ and $\mathrm{D}$ are pictured the same spatial views of Cholera toxins (1xtc) that is shown for Shigela toxin (A, B). In E and F are presented the heptameric prepore structure of protective antigen (1tzo) from B. anthracis, in lateral view and a view from the bottom, respectively. In $\mathrm{G}$ is shown the tridimensional structure of ricin (2aa1), in which the receptor binding domain predominantly composed of $\beta$-sheets, and the catalytic domain are clearly distinguished. In $\mathrm{H}$ is seen the $\mathrm{C} 2$ toxin transport component (2j42). PDB, written in lowercase, stands for Protein Data Bank of The Research Collaboratory for Structural Bioinformatics (RCSB) (http://www.rcsb.org/pdb).

a translocation pore in the membrane or early endosome or (ii) by being routed through the Golgi apparatus and to endoplasmic reticulum via retrograde transport. In the early endosome, diphteria toxin and botulinum neurotoxins, for example, are proteolytically cleaved by furin to generate heterodimeric forms of toxins that are maintained by S-S bonds. Following acidification of endosome, by protonpump ATPase, the translocation domains are inserted into vesicle membrane, what forms pores and mediates the delivery of the catalytic domains into the cytoplasm. In case of Cholera toxin, pertussis toxin, and pertussis exotoxin A, which contain the C-terminal endoplasmic reticulum-retrieval sequence-RDELK, as well as shiga toxin and the plant toxin ricin, which surprisingly do not have such sequence, the low $\mathrm{pH}$ does not influence the formation of pore for translocation. These toxins conduct the translocation of their active domains from the early endosome by using the trans-Golgi network (TGN), and then retrogradely to endoplasmic reticulum. Finaly, from endoplasmic reticulum into cytoplasm using one preexisting translocation machinery in the ER membrane, like the Sec61 translocon..$^{10-12}$

In the cytoplasm, some toxic catalytic domains are able to ADP-ribosylate the eucaryotic elongation factor 2 (eEF2), such as diphteria toxin and Pseudomonas exotoxin A, while others, like shiga toxin, possess the enzymatic activity of $\mathrm{N}$-glycosidase, removing one adenine residue from the $28 \mathrm{~S}$ ribosomal RNA (rRNA). Both catalytic activities culminate with impaired proteins synthesis of the intoxicated cells. Enzymatic activities of translocated bacterial toxins other than ADP-ribosyl transferase of eEF-2 and depurination of 28S rRNA include ADP-ribosylation of heterotrimeric G-protein (Cholera toxin and pertussis toxin), glucosyl transferase of Rho proteins (C. difficile toxins $\mathrm{A}$ and $\mathrm{B}$ ), and $\mathrm{Zn}$ endoproteolysis of vesicular docking proteins (clostridial neurotoxins). ${ }^{9,11}$

Interestingy, several binary toxins, produced by strains of genera Clostridium and Bacillus, do not bind to cell receptors as a preformed "A-B" protein complex. Toxins like Clostridium botulinum $\mathrm{C} 2$ toxin (C2), Clostridium difficile toxin (CDT), Clostridium perfringens iota toxin (1), C. spiroforme toxin (CST), Bacillus anthracis edema and lethal toxins, as well as B. cereus vegetative insecticidal protein (VIP), initiate cell intoxication first by proteolytic activation of a monomer of "B" binding component, that occurs in solution or on membrane. Activated "B" component interacts with a specific cell membrane receptor as a heptamer (preformed in solution) or as monomers that subsequently form heptamers on membrane. An enzymatic "A" component docks with the cell-bound "B" heptamer, and the receptor-holotoxin complex is internalized through receptor-mediated endocytosis into early endosomes, which become acidified by vacular-type ATPases. An acidic environment induces conformational changes in 
the heptameric " $\mathrm{B}$ " and its subsequent insertion into the endosomal membrane, what allows the translocation of "A" component into the cytoplasm. ${ }^{9} \mathrm{C} 2$ toxin, CDT, iota toxin, CST and vegetative insecticidal protein (VIP) cause ADP-ribosylation of globular acting, which induces cytoskeletal disorganization and cell death. Edema toxin is responsible for the increasing intracellular levels of cyclic AMP (cAMP) that results in edema, while lethal toxin causes proteolysis of mitogen-activated protein kinase kinases (MAPKK), what disrupts cell signaling and induces immunosupression.

Plants also produce toxins that interfere with protein synthesis and that are binary preformed proteins. Ricin, a protein found in the seeds of Ricinus communis, is one of the most studied preformed two-component (heterodimeric) plant toxin able to disrupt protein translation. Ricin binds to glycoprotein and glycolipids receptors on eucaryotic cell membrane that contain a specific residue of galactose (via its ' $\mathrm{B}$ ' lectinic receptor binding domain), then it is internalize by receptor mediated-endocytosis, and its catalytic 'A' component is translocated to the cytoplasm, where it exerts its effect. Similar to the manner of trafficking of Cholera and shiga toxins, once ricin-receptor complex is endocyted, it is transported into early endosome, transferred by vesicular transport to the TNG, then retrogradely transported to Golgi complex and, finally, into the endoplasmic reticulum. In the endoplasmic reticulum, the disulfide bonds connecting 'A' and 'B' domains are reduced and the partial unfold 'A' component is translocated across the ER membrane via the Sec61p translocon. In the cytoplasm, the ricin 'A' catalytic domain interact to sarcin-ricin domain of large ribosomal subunit RNA (28S rRNA) and removes one adenine residue, by cleavage of a single $\mathrm{N}$-glycosidic bond, generating a depurinated inactive ribosome. In addition to this specific $\mathrm{N}$-glycosidase activity on riobosomes, ricin and other ribosome-inactivating (RIPs) have a less specific in vitro action on DNA and RNA. ${ }^{13,14}$ Others known ribosome-inactivating proteins are, for example, abrin, from the seeds of Abrus precatorius; gelonin, from Gelonium multiflorum seed; saporin, from the soapwort (Saponaria officinalis) seed, leaf and root; trichosanthin, from Trichosanthes kirilowii tuber. ${ }^{14}$ Some examples of membrane translocating toxins, their structural characteristics and biochemical properties are summarized in Table 1.

In summary, bacterial, and some animal and plant, toxins use translocation mechanism based on pore formation on cell or vesicular (endosomal) membrane to have access to cell cytoplasm, while others relies their intracellular trafficking on the pre-existing translocation machinery in the ER membrane - a "chaperone" like process.
Apart from the toxicological health problems associated to bacterial intoxication, as well as the medical treatment to deal with, themes out of scope in this manuscript, the molecular engineering of catalytic and binding domain of binary toxins is of particular interest for the specific design of derivatives. Thus, chimeras of binary toxins have been constructed not only for controlling several malignant disorders, but also to serve as vaccine adjuvants and other molecular vehicles. For instance, immunotoxins - proteins composed of monoclonal antibodies, their fragments or specific proteins linked to a plant or bacterial active ' $A$ ' moiety, bind to a surface antigen on a cancer cell, enter the cell by endocytosis, delivery the toxin domain, that catalytically inhibits a critical cell function, usually protein synthesis, and triggers cell death. This elegant and precise idea of immunotoxins ('magic bullets') was planted by Paul Erlich, in the early years of 1900s.

Most effective immunotoxins have been prepared by recombinant DNA technology, by fusing pieces of genes encoding the toxin domain and the ligand of interest (e.g., antibodies and their fragments). To date, the best successful examples of use of immunotoxins have been for the treatment of hematologic tumors. ${ }^{15,16}$ Thus, in clinical phases of application, recombinant immunotoxins like $\mathrm{DAB}_{486} \mathrm{IL} 2$ (fragment 1 to 486 of diphteria toxin - DAB fused to interleukin 2 - IL2), Denileukin diftitox $\left(\mathrm{DAB}_{389}\right.$ - IL2), LMB-2 (fragment of Pseudomonas exotoxin A PE38 fused to antibody to the CD25 receptor) and BL22 (PE38 - anti-CD22), have been used to treat lymphoma and leukemia, while Anti-B4-bR (anti-B4 blocked ricin fused to anti-CD19), DTGM (fragment 1 to 388 of diphteria toxin - $\mathrm{DT}_{388}$ fused to human granulocyte-macrophage colony stimulating factor, hGM-CSF) are in use against non-Hodgkin's lymphoma, and acute myelogenous leukemia, repectively (for more examples, refer to Table 1, in Pastan et al. ${ }^{16}$ ). Clinical trials of immunotoxins for treatment of solid tumors are being conducted principally with recombinant fragments of ricin or pertussis toxin and monoclonal antibodies and their fragments. These hybrid immunotoxins target cell surface receptors or antigens that are mainly expressed on tumor cell membrane. For example, LMB-9 (NCI B3(dsFV)-PE38) recognizes Lewis-Y antigen present on the glycoproteins of several adenocarcinomas and is used to fight againts breast, colon, stomach, and pancreas cancer. SS1P is a hybrid of PE38 and anti-mesothelin, that targets tumors that express mesothelin, like mesotheliomas, pancreas, ovary, cervix, lung, nasopharynx, and oesophagusmesothelin. ${ }^{16,17}$

Since toxin binding ' $\mathrm{B}$ ' domain facilitate the translocation of an active 'A' domain, recombinant hybrids can also be used to delivery antiviral and antigenic peptides to major 
Table 1. Some examples of membrane translocating toxins, their structural characteristics and biochemical properties

\begin{tabular}{|c|c|c|c|c|c|c|}
\hline Source & Toxin & Structure & $\begin{array}{l}\text { Receptor on cell } \\
\text { membrane }\end{array}$ & $\begin{array}{l}\text { Main mechanism } \\
\text { of membrane } \\
\text { translocation }(*)\end{array}$ & $\begin{array}{l}\text { Biological activity } \\
\text { of 'A' moiety }\end{array}$ & Intracelular target \\
\hline \multicolumn{7}{|c|}{ Preformed binary ('A-B') toxins } \\
\hline $\begin{array}{l}\text { Clostridium } \\
\text { botulinum }\end{array}$ & $\begin{array}{l}\text { Botulinum } \\
\text { neurotoxins }\end{array}$ & A-B & Synaptotagmin II & RME, EE & Zinc endoprotease & $\begin{array}{l}\text { VAMP, SNAP-25, } \\
\text { syntaxin1 }\end{array}$ \\
\hline C. difficile & Toxins A and B & A-B & Glycans & RME, EE & Glucosyl transferase & Rho proteins \\
\hline C. tetani & Tetanus neurotoxin & A-B & Neuronal Thy-1 & RME/CVE, EE & Zinc endoprotease & $\begin{array}{l}\text { VAMP } \\
\text { (synaptobrevin) }\end{array}$ \\
\hline $\begin{array}{l}\text { Corynebacterium } \\
\text { diphteria }\end{array}$ & Diphteria toxin & A-B & $\begin{array}{l}\text { for HB EGF-like } \\
\text { GF }\end{array}$ & $\mathrm{RME} / \mathrm{CDE}, \mathrm{EE}$ & $\begin{array}{l}\text { ADP-ribosyl } \\
\text { transferase }\end{array}$ & $\begin{array}{l}\text { Elongation factor } 2 \\
(\text { EF-2) }\end{array}$ \\
\hline Bordetella pertussis & Pertussis toxin & $\mathrm{A}-(\mathrm{B})_{5}$ & Glycoproteins & $\begin{array}{l}\text { RME, } \\
\text { ER-trafficking }\end{array}$ & $\begin{array}{l}\text { ADP-ribosyl } \\
\text { transferase }\end{array}$ & $\begin{array}{l}\text { HeterotrimericG- } \\
\text { protein }\end{array}$ \\
\hline $\begin{array}{l}\text { Pseudomonas } \\
\text { aeruginosa }\end{array}$ & Exotoxin A & A-B & LRP & $\begin{array}{l}\text { RME/CDE, } \\
\text { ER-trafficking }\end{array}$ & $\begin{array}{l}\text { ADP-ribosyl } \\
\text { transferase }\end{array}$ & $\begin{array}{l}\text { Elongation factor } 2 \\
\text { (EF-2) }\end{array}$ \\
\hline Shigela & Shiga toxin & $\mathrm{A}-(\mathrm{B})_{5}$ & Glycolipid Gb3 & $\begin{array}{l}\text { RME/CCP, } \\
\text { ER-trafficking }\end{array}$ & N-glycosylase & $28 \mathrm{~S}$ rRNA \\
\hline Vibrio cholera & Cholera toxin & $\mathrm{A}-(\mathrm{B})_{5}$ & Ganglioside GM1 & $\begin{array}{l}\text { RME/CCP, } \\
\text { ER-trafficking }\end{array}$ & $\begin{array}{l}\text { ADP-ribosyl } \\
\text { transferase }\end{array}$ & $\begin{array}{l}\text { HeterotrimericG- } \\
\text { protein }\end{array}$ \\
\hline $\begin{array}{l}\text { Rinius communis } \\
\text { (plant) }\end{array}$ & Ricin & A-B & $\begin{array}{l}\beta-1,4 \text { linked } \\
\text { galactosides }\end{array}$ & $\begin{array}{l}\text { RME/CCI, } \\
\text { ER-trafficking }\end{array}$ & N-glycosylase & 28S rRNA \\
\hline \multicolumn{7}{|c|}{ In-receptor or in-solution formed binary ('A-B') toxins } \\
\hline Bacillus anthracis & Edema toxin & $\mathrm{EF}-(\mathrm{PA})_{7}=\mathrm{A}-(\mathrm{B})_{7}$ & TEM 8, CMG2 & RME, EE & Adenylate cyclase & $\begin{array}{l}\text { cAMP-dependent } \\
\text { proteins }\end{array}$ \\
\hline B. anthracis & Lethal toxin & $\mathrm{LF}-(\mathrm{PA})_{7}$ & TEM 8, CMG2 & RME, EE & Zinc endoprotease & MAPKK \\
\hline B. cereus & VIP & VIP1-(VIP2) ${ }_{7}$ & Unknown & RME, EE & $\begin{array}{l}\text { ADP-ribosyl } \\
\text { transferase }\end{array}$ & Globular actin \\
\hline $\begin{array}{l}\text { Clostridium } \\
\text { botulinum }\end{array}$ & $\mathrm{C} 2$ toxin & $\mathrm{C} 2 \mathrm{I}-(\mathrm{C} 2 \mathrm{II})_{7}$ & Glycoproteins & RME, EE & $\begin{array}{l}\text { ADP-ribosyl } \\
\text { transferase }\end{array}$ & Globular actin \\
\hline C. difficile & CDT & $\mathrm{CDTa}-(\mathrm{CDTb})_{\urcorner}$ & Unknown & RME, EE & $\begin{array}{l}\text { ADP-ribosyl } \\
\text { transferase }\end{array}$ & Globular actin \\
\hline \multicolumn{7}{|l|}{ C. perfringens } \\
\hline & $t$ toxin & Ia-(Ib) & $\begin{array}{l}\text { Uncharacterized } \\
\text { protein }\end{array}$ & RME, EE & $\begin{array}{l}\text { ADP-ribosyl } \\
\text { transferase }\end{array}$ & Globular actin \\
\hline
\end{tabular}

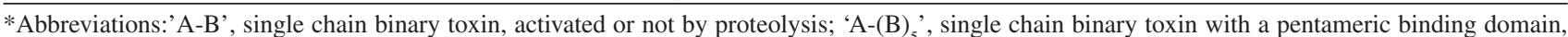
activated by proteases; 'A-(B) ', binary tozin with a heptameric binding domain that is oligomerized in receptor or in solution after proteolytic activatiom; EF, Edhema factor; LF, lethal factor; PA, protective antigen (EF and LF are 'A' moities of B. anthacis toxins, while PA is the 'B' moiety); HB EGF-like GF, Heparin-binding EGF-like growth factor; LRP, low-density lipoprotein receptor-related protein; TEM 8, tumor endothelial marker; CMG2, human capillary morphogenesis gene 2; RME, receptor-mediated endocytosis; CDE, clathrin-dependent endocytosis; $\mathrm{CCP}$, clatrhin-coated pits; $\mathrm{CCI}$, clathrin- and caveolin-independent endocytosis; Caveolin-dependent endocytosis (caveolar endocytosis), EE (Early endosome), route through acidified early endosome; ER-trafficking, endoplasmic reiticulum route, through the Golgi apparatus ("retrograde vesicular transport or retrogarde pathway). (*) Some toxins have more than one type of mechanism of membrane translocation, like cholera toxin that use clatrhin-independent pathawy, but caveolin-dependent. This table was based on reference cited in the text. ${ }^{9-12}$

histocompatibility complex I (MHC I) molecules and, in fact, several toxin B-chain have been tested for specific 'vaccination'. ${ }^{18}$ As additional example of application, the protective antigen (PA), the core receptor-binding component of Anthrax toxin, which delivers the catalytic effector molecules - lethal factor (LF) or edema factor (EF) into the cytosol of mammalian cells, has been used to deliver DNA to the cytoplasm. Gaur and co-authors expressed a recombinant fusion protein consisting of the PA binding domain of the N-terminal 254 amino acids of $\mathrm{LF}\left(\mathrm{LF}_{254}\right)$ and the DNA-binding domain of the yeast transcription factor GAL4 (GAL-DBD), and showed that this fusion protein in combination with PA can deliver plasmid DNA containing a reporter gene and a GAL4 specific recognition sequence into the cytosol of mammalian cells.

\section{Antimicrobial Peptides}

It is not only bacterial toxins that utilize pore forming and membrane trafficking systems to get into the cytoplasm and intoxicate mammalian cells. Animals - from arthropods to human - are also equipped with peptides that kill microbial cells by disrupting the cytoplasmic membrane functions. 
Antimicrobial peptides (AMPs) are essential components of innate immunity of invertebrates, plants and animals, acting as the first line of defense against invading microbes. So, to evolve and thrive in an environment dominated by a myriad of microorganisms, it was a necessity of all living organisms to produce AMPs.

The research about antimicrobial peptides began during the late 19th century with the independent works of Ehrlich, Metchnikov, Kanthack, and Peterson. In 1879, Ehrlich defined the cytoplasmic granules of the granulocytic white blood cells and inferred from staining properties that these cells carry basic proteins or a mixture of acidic and basic ones. In 1883, Metchnikov described, the preeminence of phagocytes in antimicrobial host defenses. Kanthack and Hardy discovered, in 1895, that phagocytosis of bacteria induced granulocytes to degranulate. Afterwards, Peterson found antimicrobial activity in aqueous extract of pus, and compared the action of basic protein he found to protamine from salmon sperm. In 1963, Zeya and Spitznagel convincingly showed the existence of cationic antimicrobial proline-rich granules in neutrophils of guinea pigs, rabbits and humans. ${ }^{20}$ In the 70 's, the first plant antimicrobial peptides, belonging to the group of thionins (plant defensins), were isolated. ${ }^{21}$ Later on, the field of AMPs expanded when researchers also independently isolated and purified the cecropins, from the pulp of silkworm, Bombix mori; ${ }^{22}$ the magainin, from the skin of the amphibian Xenopus; ${ }^{23}$ and mammalian defensins. ${ }^{24}$ Excellent reviews cover many aspects of the field of gene-enconded, ribosomally synthesized antimicrobial peptides. ${ }^{25-31}$ The molecular diversity of antimicrobial peptide is immense and almost a thousand of structures have already been characterized. Plenty of information can also be retrieved from specialized databases like AMSDb (http://www.bbcm.univ.trieste.it/ tossi/amsdb/html) and ANTIMIC (http://research.i2r.a-star.edu.sg/Templar/DB/ ANTIMIC/).

Structures of antimicrobial peptides encompass molecules ranging in size of 6 to 60 amino acid residues, being linear ( $\alpha$-helical and non-helical AMPs), cyclic (Rhesus $\theta$-defensins, RTDs) or cross-linked by one, two, three, or more internal disulfide bridges. Mammalian $\alpha$-and $\beta$-defensins and insect defensins constitue the group of AMPs structured by three disulfide bonds. In terms of amino acid composition and net surface charge, they may be rich in one type of amino acid residues (Pro-rich, Pro/ Gly-rich, Trp-rich, His-rich, His/Gly-rich, and Lys- or Arg-rich), confering variable indexes of hydrophobicity, amphipathicity, net positive charge and, in minor cases, net negative charge to these molecules. ${ }^{25,27}$ Fragments of protein domains can also present antimicrobial properties.
For instance, the carboxyl terminal thirty amino acids of the $\beta$-subunit of human hemoglobin, which forms a cationic $\alpha$-helix is active against Escherichia coli, Staphylococcus aureus and Candida albicans. ${ }^{32}$ Antimicrobial peptides are also generated by cleavage of $\alpha$-casein by strains of Lactobacillus acidophilus. Three casein-derived AMPs (IKHQGLPQE, VLNENLLR, and SDIPNPIGSENSEK) showed antibacterial activity against pathogenic strains of Enterobacter sakazakii and Escherichia coli. ${ }^{33}$

Although AMPs are structurally diverse, they conserve the functional ability to interact to and insert into the lipid bilayer of microbial cells. The phospholipid membrane of microorganism are composed of peptidoglycan and lipoteichoic acid (Gram positive bacteria) and lipopolysaccharides (LPS, Gram negative bacteria), what confer a negatively charged surface by which cationic and amphipathic AMPs are electrostatically attracted. One of the most immediate killing mechanism, intrinsic to some antimicrobial peptides (e.g., magainin, protegrin and melittin), is the formation of pore and/or channel in the membrane, then causing extensive rupture of membranes, by which metabolites leak and cell lysis occur. Three models of peptide insertion and membrane permeabilization are reported: toroidal pore, carpet and barrel stave (helicalbundle model). Following attraction, $\alpha$-helical peptide, $\beta$-sheet peptides and $\theta$-defensins are inserted into the lipid bilayer in accord to the peptide/lipid ratio and to one of these three models (reviewed in Brodgen ${ }^{34}$ ). In the 'toroidal pore model', $\alpha$-helices of AMPs, like magainin, protegrin and melittin, insert into the membrane and induce lipid monolayers to bend continuously through the pore so that the water core is lined by both the inserted peptides and the lipid head groups. In the 'carpet model', AMPs accumulate on the lipid bilayer surface, which are orientated in the plane of membrane. When high concentration is attained, peptides re-orient and AMPs aggregates insert into the membrane and disrupt it by producing micelles in a detergent like manner. AMPs that act by the 'carpet model' are represented by cecropin, dermaseptin and again melittin. Finally, in the 'barrel-stave model', antimicrobial peptide $\alpha$-helices from a bundle in the membrane, where the hydrophobic stretches of inserted peptides align with the lipid core region of the bilayer and the hydrophilic peptide stretches form the pore lining. Thus, these three mechanisms contribute to form pore, channels and to provoke membrane disruption and cell killing.

Although the formation of transmembrane pores or channels is the principal mechanism of action of antimicrobial peptides, some of their members can translocate the cell membrane without causing any damage to the lipid bilayer and interfer with intracellular 
targets. For instance, the antimicrobial peptide buforin 2 discovered in the stomach tissue of the Asian toad Bufo bufo gargarizans efficiently crosses lipid bilayers without inducing severe membrane permeabilization or lipid flipflop. ${ }^{35}$ Interestingly, the hybrid buforin II-magainin 2, in which the proline hinge region of buforin II was fused to the amino-terminal helix of magainin 2 , is able to translocate the bacterial membrane and delivery into the cytoplasm the antimicrobial $\alpha$-helical portion of magainin 2 .

Also, it was demonstrated that the proline-rich antimicrobial peptide Bac7(1-35) is rapidly taken up into 3T3 and U937 cells through a nontoxic energy- and temperaturedependent process, probably by macropinocytosis and direct membrane translocation. Additional, investigations also reveal the intracellular uptake of Bac7(1-35) by 3T3 cells is enhanced during $\mathrm{S}$ phase, suggesting a novel function for this proline-rich peptide. ${ }^{36}$ The horseshoe crab antimicrobial peptide Polyphemusin I is an amphipathic, beta-hairpin connected by a type I' beta-turn that also has membrane translocation activity, in which the beta-sheet structure is required for maximum antimicrobial activity and for crossing membrane. ${ }^{37}$ Another antimicrobial peptide able to translocate membrane is histatin 5, a 24-residue peptide from human saliva with antifungal properties. It was demonstrated that histatin 5 translocates across the yeast membrane and targets to the mitochondria, indicating that the salivary protein histatin 5 exerts its antifungal function through a mechanism other than pore formation. ${ }^{38}$ The small antimicrobial peptide PAF26 (Ac-RKKWFW$\mathrm{NH}(2)$ ), identified by a combinatorial approach, showed preferential activity toward filamentous fungi. Thus, the short PAF26 is a penetratin-type peptide that has multiple detrimental effects on target fungi. Fluorescently labeled PAF26 was used to observe the in vivo translocation that occurs inside germ tubes and hyphal cells, at concentrations as low as $0.3 \mathrm{M}$ (20 times below the minimal inhibitory concentration, MIC). In vitro activity analysis of PAF26 demonstrated its nonspecific binding to RNA.

From the point of view of clinical application, some AMPs are potential candidates for lead drugs not only as antimicrobial agents. They exhibit antitumoral and mitogenic activities, play roles in signalling transduction and adaptative immune response. ${ }^{39}$ For instance, the antimicrobial peptide magainin shows in vitro antitumoral activity by triggering apoptosis of human promyelocytic leukemia HL-60 cells. The cell death induced by magainin occurs via cytochrome $c$ release accompanied by a substantial increase of proteasome activity. ${ }^{40}$ Magainin also exerts cytotoxic and antiproliferative activity against bladder cancer cells but has no effect on normal murine or human fibroblasts. ${ }^{41}$ One biochemical reason for the action of some AMPs as antitumoral is based on the differential lipid composition of tumor cells.

In contrast to the antiproliferative effect of these AMPs, mentioned above, the porcine antimicrobial peptide, PR-39, alters macrophage viability by inhibiting apoptosis through of decreasing the caspase- 3 activity, what suggests that this antimicrobial peptide might function in the inflammatory response not only by killing bacteria, but also by aiding in the modulation of the viability of inflammatory cells. ${ }^{42}$ More examples are known, but will not be extensively discussed here. Several antimicrobial peptides and their derivatives are in distinct phases of clinical trial of application and are described elsewhere. ${ }^{30,43}$ In Table 2, the primary and secondary strucures of some antimicrobial peptides, as well as their action on membrane and other cell targets, are summarized.

\section{Cell Penetrating Peptides and Crotamine}

Another particular class of membrane-active peptides encompasses the cell penetrating peptides (CPPs), formerly referred as protein transduction domains (PTDs) or membrane transdcution domains (MTPs). Cell penetrating peptides are short cationic or amphipathic peptide sequences with high affinity for lipid membranes, able to translocate membrane systems, and to mediate the intracellular delivery of polymeric biomolecules, drugs and nanoparticles.

The first CPPs were recognized in two transcription factors: the Tat protein, from HIV-1, and the Antennapedia (Antp), from the Drosophila fruit fly. ${ }^{44,45}$ Later on, short peptide fragments of Tat protein (e.g., Tat $_{47-57}$ and Tat ${ }_{48-60}$ ) and a segment of 16 amino acids of Antennapedia homeodomain (Antp ${ }_{43-58}$, named 'Penetratin') were demonstrated to be sufficient to translocate through the plasma membranes. ${ }^{46,47}$ Since then, an increasing number of natural and synthetic CPPs have been utilized to translocate and delivery into the cell cytoplasm and nucleus heterologous protein, nucleic acid, drugs, and biomaterials with nanometric dimension, both in vitro and in vivo. ${ }^{48-51}$ Some examples of CPPs are presented in Table 3.

Due to their physical and chemical characteristics (short length, cationic, amphipatic, and structured arranged peptides), CPPs are quite similar to AMPs and, consequently, share the fundamental property of strong interaction with lipid membranes. However, AMPs, as above mentioned, predominantly translocate into the cell by transient pore formation in the membrane, while CPPs enter into the cell by several mechanisms that include all types of receptor-mediated endocytosis. Delivery of HIVTat involves caveolae, clathrin-coated pit and vesicles, or macropinocytosis, although lipid raft-dependent and 
Table 2. Examples of antimicrobial peptides, their primary and secondary structures and mode of interaction with lipid membrane

\begin{tabular}{|c|c|c|}
\hline \multirow[t]{2}{*}{ Peptide } & Amino acid sequences & Action on membrane and other targets \\
\hline & \multirow[b]{2}{*}{ TRSSRAGLQFPVGRVHRLLR } & \\
\hline Buforin 2 & & $\begin{array}{l}\text { Translocation } \\
\text { DNA binding }\end{array}$ \\
\hline Cecropin A & KWKLFKKIEKVGQNIRDGIIKAGPAVAVVGQATQIAKamide & Pore-forming \\
\hline Magainin 2 & GIGKFLHSAKKFGKAFVGEIMNS & $\begin{array}{l}\text { Pore-forming } \\
\text { DNA synthesis inhibition }\end{array}$ \\
\hline $\begin{array}{l}\text { Hybrid cecropin A- } \\
\text { magainin } 2\end{array}$ & KAKLFKKIGIGKFLHSAKKFG & $\begin{array}{l}\text { Membrane disruption } \\
\text { Lower hemolytic activity }\end{array}$ \\
\hline $\begin{array}{l}\text { Hybrid buforin II- } \\
\text { magainin } 2\end{array}$ & RAGLQFPVGGIGKFLHSAKKFGK & $\begin{array}{l}\text { Translocation } \\
\text { DNA synthesis inhibition }\end{array}$ \\
\hline & \multicolumn{2}{|l|}{ Linear non $\alpha$-helical } \\
\hline PR-39 & RRRPRPPYLPRPRPPPFFPPRLPPRIPPGFPPRFPPRFPamide & $\begin{array}{l}\text { Translocation } \\
\text { DNA synthesis inhibition }\end{array}$ \\
\hline Histatin & DSHAKRHHGYKRKFHEKHHSHRGY & $\begin{array}{l}\text { Translocation } \\
\text { Enzyme inhibition }\end{array}$ \\
\hline \multicolumn{3}{|c|}{ Cross-linked by three disulfide bonds } \\
\hline Human $\alpha$-defensin & VCSCRLVFCRRTELRVGNCLIGGVSFTYCCTRV & $\begin{array}{l}\text { Membrane permeabilization } \\
\text { DNA synthesis inhibition }\end{array}$ \\
\hline Human $\beta$-defensin & GLGHRSDHYNCVSSGGQCLYSACPIFTKIQGTCYRGKAKCCK & Membrane permeabilization \\
\hline Plant defensin & RTCMIKKEGWGKCLIDTTCAHSCKNRGYIGGNCKGMTRTCYCLVNC & $\begin{array}{l}\text { Membrane permeabilization } \\
\text { Vesicle aggregation }\end{array}$ \\
\hline \multicolumn{3}{|c|}{ Circular } \\
\hline$\theta$-defensin & RRICRCICGRGICRCICG & Bind to glycoproteins on virus surface \\
\hline
\end{tabular}

Table 3. Sequences of some membrane-translocating/cell penetrating peptides

\begin{tabular}{|c|c|}
\hline Peptide & Amino acid sequences \\
\hline \multicolumn{2}{|l|}{ Cationic } \\
\hline HIV1 TAT $_{47-57}$ & YGRKKRRQRRR \\
\hline HIV1 $_{1}$ TAT $_{48-60}$ & GRKKKRRQRRRPPQ \\
\hline Drosophila Ant $_{43-58}$ (Penetratin) & RQIKIWFQNRRMKㅌK \\
\hline Poli-lisina (R7, sintético) & RRRRRRR \\
\hline PTD-5 (sintético) & RRQRRTSKLMKR \\
\hline
\end{tabular}

Amphipathic

Buforin 2

Transportan (chimera)

Transportan 10

KALA (sinthetic)

CL22

Crotamine

TRSSRAGLQFPVGR $\underline{\text { HHRLLR }}$

GWTLNS $\underline{A G Y L L G K I N L K A L A A L A K K I L ~}$

AGYLLGKINLKALAALAKKIL

WEAKLAKALAKALAKHLAKALAKALKACEA

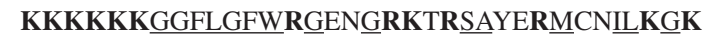

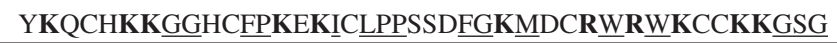

Amino acid sequences are represented by one code letter symbols. Positively charged amino acids are shown in boldface and nonpolar amino acid residues are underlined.

clathrin-independent endocytosis seems to be alternative mechanisms of cellular uptake. ${ }^{52-56}$ Indeed, the translocation mechanism of CPPs is complex and may involve more than one single mode. Whatever the pathway CPPs use to translocate membrane (trafficking) systems, it has been proved that they can serve to delivery molecules 
inside the cells and into their internal compartments, like endosomes, nucleus, and mitochondria. For instance, penetratin $\left(\right.$ Antp $\left._{43-58}\right)$ is able to transport into the cell short polypeptides (up to 100 residues of amino acid), ${ }^{57}$ while VP22 (a strucutral polypeptide of Herpes simplex vírus type I, HSV-1 $)^{58}$ and HIV-1 Tat ${ }_{48-60}$ can translocate larger polypeptides, like the enzymes $\beta$-galactosidase and thymidine kinase, as well as the protein p53 and other cargos of various sizes and physicochemical properties. ${ }^{59-63}$

CPPs constitute a very reliable alternative to other transfections systems. For example, although adenoviral vectors can efficiently transduce a broad variety of different cell types they can still trigger transient toxic effects in animals and patients. Moreover, integrating adenoviral vectors carry a greater malignancy risk due to their ability to integrate randomly into the target genomes. ${ }^{64}$ In relation to chemical and physical methods of transfection, like complexes between DNA and diverse polycations ('polyplexes') or cationic lipids ('lipoplexes'), microinjection, electroporation and particle bombardment ('gene gun') ${ }^{65}$, CPPs offer the possibility to deliver genes and other biomolecules to specific population of target cells with improved efficiency.

In 2004, our group reported a remarkable finding in the field of molecular toxinology and of transducing technology. By using mouse embryonic stem cells (mES cells), we demonstrated that crotamine, a cationic peptide from the venom of the South American rattlesnake (Crotalus durissus terrificus), selectively translocate into actively dividing cells both in vivo and in vitro, in a matter of minutes and in a time- and concentration-independent fashion. ${ }^{66}$ Crotamine did not show any toxic effect on $\mathrm{mES}$ cells in vitro, in micromolar concentrations. By tracking the fluorescent derivative of crotamine inside the proliferactive cells (AP cells) it was possible to localize the peptide in the nucleus. Since crotamine penetrates into cells during G1/S period and binding to centrosomes and chromosomes, we have proposed the use of crotamine as a marker of centrioles, of cell cycle and of actively proliferating (AP) cells. This exclusive cell cycle dependent-penetration of crotamine indicates that this snake venom peptide is distinct of any other known natural CPPs. Additional studies revealed that crotamine was also capable of binding electrostatically to plasmid DNA, forming DNA-peptide complexes - delivery of the plasmid DNA into AP cells, both in vitro and in vivo, which distinct crotamine from other known natural CPPs (Figure 2). Another hallmark was the deciphering of the mechanism of crotamine translocation. The mechanism of crotamine penetration and cargo delivery involves the initial binding to heparan sulfate proteoglycans in the uptake, followed by endocytosis and peptide accumulation within the acidic endosomal vesicles. Moreover, the permeabilization of endosomal membranes induced by crotamine results in the leakage of the vesicles contents to the cell cytosol. ${ }^{67}$ The endosomolytic pathway, used by crotamine to gain access to the cell cytoplasm is another advantage of this natural peptide, that has been explored by several research groups for the effective delivery of drugs. For instance, a penetrating analog named EB1, is protonated in the early-late endosome, forming an amphipathic alpha helix that permeabilize the endosomal membrane. This endosomolytic mechanism of delivery significantly increase the efficiency of short interfering RNA (siRNA) uptake and demonstrated that endosomolysis is a necessary step toward tranportation of low concentration of active compounds for in vivo application..$^{68}$ Despite of improved efficiency of peptide translocation via endosomolytic pathway, all type of endocytosis (clathrin-dependent, raft/ caveolin-dependent and macropinocytosis) are implicated in the uptake of CPPs, as mentioned above, particularly the peptides rich in arginine, which are transported into specific intracellular (nuclear) compartments. ${ }^{69}$

It is worthy of note that crotamine is a highly basic toxin, rich in Lys, with an amphipathic character, which was originally purified from a venom fraction of Crotalus durissus terrificus. ${ }^{70}$ Crotamine is a low molecular weight peptide $(4.8 \mathrm{kDa})$, of 42 amino acid residues (YKQCHKKGGHCFPKEKICLPPSSDFGKMDCRWRW KCCKKGSG), cross-linked by three disulfide bonds (Cys4-Cys36, Cys11-Cys30 and Cys18-Cys37). Its threedimensional structure, as determined by NMR, is arranged as apha-beta-beta-beta $(\alpha \beta \beta \beta){ }^{71-72}$ Such type of fold is found in the classes of human $\beta$-defensins (Figure 3 ) and scorpion toxins that target $\mathrm{Na}^{+}$-channels. ${ }^{73}$ Thus crotamine shares the functional properties of cell penetration with most CPPs and the structural characteristics with the classes of both membrane-active peptides: AMPs and CPPs. However, any antimicrobial activity was yet attributed to crotamine. Unmodified (naïve) crotamine and their potential derivatives are being proposed by us to be used as a new gene delivery system, and for other applications like nanometric biological tools (nano-biotools) and molecular diagnostic of proliferactive cells (tumor cells).

Another interesting natural cell penetration peptide, recently characterized, is maurocalcine. Maurocalcine, isolated from the venom of the scorpion Scorpio maurus maurus, is a 33-amino acid residues peptide toxin (GDCLPHLKLCKENKDCCSKKCKRRGTNIEKRCR) also cross-linked by three disulfide bridges (Cys3Cys17, Cys10-Cys21 and Cys16-Cys32). Its structural and functional features make it resembling many cell penetrating peptides. Maurocalcine produces $\mathrm{Ca}^{2+}$-release 

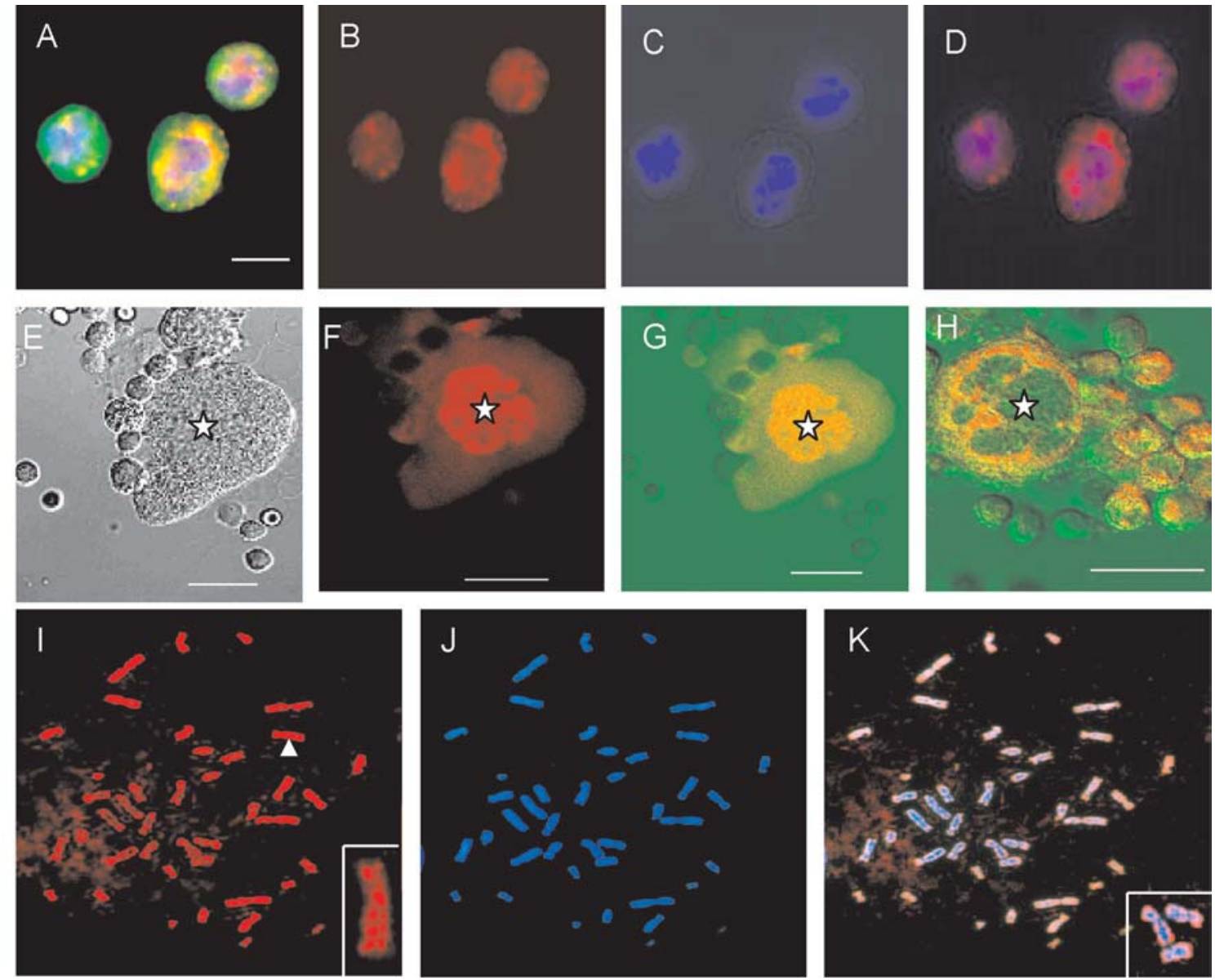

Figure 2. In vitro and in vivo nuclear localization of Cy3-crotamine and its association with mitotic chromosomes. (A-D) Internalization of Cy3-crotamine, $3 \mathrm{~h}$ after injection into mice, observed in nuclei (asterisk) and perinuclear space (arrow) of peritoneal liquid cells. (A) Cy3-crotamine. (B) Nuclei stained by DAPI (blue). (C) Superimposed images (A) and (B): partial overlapping (pink) of Cy3-crotamine localization (red) and DAPI staining in nuclei (arrow). (D) Superimposed images (A) and (B), demonstrating overlapping (pink) of Cy3-crotamine localization and DAPI staining within the nuclei, and overlapping (yellow) of cytoskeleton immunostained with anti-tubulin antibody (green) and Cy3-crotamine in perinuclear space $(\mathrm{A}-\mathrm{D}=\mathrm{Epifluorescence,} \mathrm{EF}$; bar $=50$ $\mu \mathrm{m})$. (E-G) Cy3-crotamine strong labeling in nucleus (asterisk) and weak fluorescence in cytoplasm of mouse megakaryocyte $(\mathrm{E}=\mathrm{Dic}, \mathrm{F}=\mathrm{Fcm}, \mathrm{G}=\mathrm{Dic}+$ $\mathrm{Fcm}$; bars $=25 \mu \mathrm{m})$. $(\mathrm{H})$ Cells pretreated with non-labeled crotamine followed by Cy3-crotamine treatment. Strong fluorescence restricted to the cytoplasm indicates saturation of binding sites by non-labeled crotamine in the nucleus (asterisk), as clearly observed in the megakaryocyte (Dic $+\mathrm{Fcm} ; \mathrm{Bar}=10 \mu \mathrm{m})$. (I-K) Metaphase of lymphoblastic cell. (EF; Magnification, 800x). (I) Cy3- crotamine labeled chromosomes. A banding pattern is produced as shown by the chromosome in the inset. (J) DAPI-stained chromosomes. (K) upper position of images (I) and (J): Crotamine labeling (red) is observed on DAPI-stained chromosomes. In the inset, the association of crotamine with DAPI-stained chromosomes is depicted (arrow).

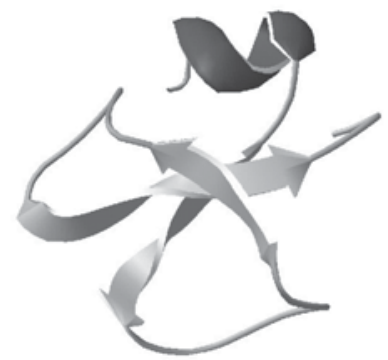

$1 \mathrm{~h} 5 \mathrm{o}$

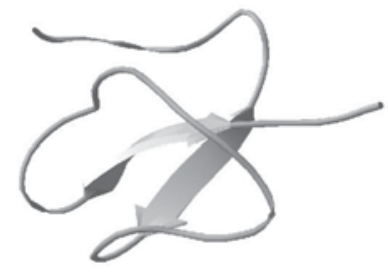

$1 e 4 q$

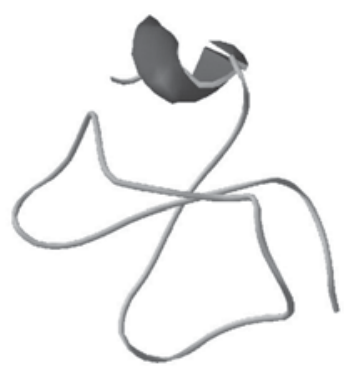

$1 z 99$

Figure 3. Comparison of spatial structures of crotamine and human $\beta$-defensin 2. Structures were accessed by means of the structure explorer engine from the Protein Data Bank of The Research Collaboratory for Structural Bioinformatics (RCSB) (http://www.rcsb.org/pdb). In one solution structure of crotamine, pdb 1h5o, the antiparallel $\beta$-sheets were attributed, while in the NMR model 'pdb 1z99' they could not be. Both crotamine solution structures share the same overall scaffold with human $\beta$-defensin $2(\mathrm{pdb} 1 \mathrm{e} 4 \mathrm{q}) . \beta$-sheets are represented in light gray and $\alpha$-helices are in dark gray. 
from intracellular stores within seconds. It binds directly to the skeletal muscle isoform of the ryanodine receptor, an intracellular channel target of the endoplasmic reticulum, and induces long-lasting channel openings in a mode of smaller conductance. Boisseau et al. ${ }^{74}$ prepared a biotinylated derivative of this scorpion peptide (MCab) and coupled to a fluorescent streptavidin indicator ( $\mathrm{Cy} 3$ or $\mathrm{Cy} 5$ ). They followed the cell penetration of the entire complex and observed the initial interaction with the disialoganglioside GD3 - one of the most abundant charged lipid in natural membranes. Evidences indicate that maurocalcine may cross the plasma membrane directly by cell translocation and might carry various drugs and agents of therapeutic and diagnostic.

Taking into consideration that in several cases AMPs behave as CPPs, Takeshima and collaborators ${ }^{75}$ investigated the cellular uptake of fluorescent analogues of the two representative natural antimicrobial peptides magainin 2 and buforin 2 and compared with the representative Arg-rich cell-penetrating HIV1-Tat ${ }_{47-57}$ peptide (YGRKKRRQRRR). The dose, time, temperature, and energy dependence of translocation suggested that the three peptides cross cell membranes through different mechanisms. The magainin peptide is internalized within a time scale of tens of minutes. The cooperative concentration dependence of uptake suggested that the peptide forms a pore as an intermediate similar to the observations in model membranes. Furthermore, the translocation was coupled with cytotoxicity, which was larger for tumor HeLa cells. In contrast, the buforin peptide translocates within 10 min by a temperature-independent, less concentration-dependent passive mechanism without showing any significant cytotoxicity at the highest concentration investigated $\left(100 \mu \mathrm{mol} \mathrm{L} \mathrm{L}^{-1}\right)$. The buforin peptide, covalently attached to the $28-\mathrm{kDa}$ green fluorescent protein, also entered cells, also suggesting the potential use of this peptide as a vector for macromolecular delivery into cells.

As pointed out above, several others antimicrobial peptide can penetrate the cell and exert their biological action. In any case, the comprehension of the mechanism of membrane trafficking used by AMPs to get into the cell deserves more detailed studies. Therefore, experimental methods to evaluate and quantify translocation processes mediated by AMPs and CPPs, in vivo and in vitro, with or without attached macromolecular cargoes should be criteriosly selected. ${ }^{34,76,77}$ Thus far, the question "How different are cell-penetrating peptides and antimicrobial peptides?", intended to be answered by several investigators, is still elusive. After all, we may share the same point of view of Henriques and collaborators: $:^{78}$ "Potentially, all CPPs are AMPs and all AMPs are CPPs".
A clear point is that these peptides (AMPs and CPPs) have profoundly diverged, as testified by innumerous structures, but still preserving the functional property of interacting with membrane and persuading the membrane trafficking system. Interestingly, similar point of view can be shared concerning to $\beta$-PFTs and ' $\mathrm{B}$ ' moiety of binary toxins - both are $\beta$-hairpins that acquired the specilized function of pore-formation. ${ }^{1}$ While $\beta$-PFTs perforate cytoplasmic membrane, ' $\mathrm{B}$ ' moiety insert into the endosomal membrane after acidification of endosome, forming a pore by which ' $\mathrm{A}$ ' moiety is delivered to the cytosol.

The increased interest upon CPPs relies on their use as target-specific non-invasive delivery technology for drugs, heterologous proteins and genes, oligonucleotides and nanomaterials The molecular delivery can be addressed either to the cytoplasm or to the nucleus of the target cells. ${ }^{48-50,77,79}$ Moreover, potential applications of CPPs as delivery systems include different areas of vaccine development, cancer immunotherapy, gene delivery, and cellular imaging. ${ }^{80-82}$

\section{Concluding Remarks}

Although binary toxic proteins (pore-forming and membrane-trafficking), antimicrobial peptides and cell penetrating peptides are quite dissimilar classes of membrane-acting peptide and toxins, they all conserve the ability to open a passage through the cell membrane or to persuade the membrane trafficking system to exert their biological action inside the cell. Pore-forming toxins interact first to their receptors that are concentrate in microdomains regions on cell membrane (lipid raft), while most binary toxins use receptor-mediated endocytosis. From this point, toxins perfurate the cytoplasmic membrane (cytolysins) or gain access to the cell cytoplasm via early endosome. Once in the early endosome, they reach the cytoplasm or other intracellular compartment via retrograde tranport or endosome sorting. The mechanism of pore-formation of antimicrobial peptides has been extensively studied and many biophysical aspects are known today. On the other hand, translocation of cellpenetrating peptide is under intensive investigation. Both, antimicrobial peptides and cell-penetrating peptides seem to interfer with cell membrane in the same way. Most antimicrobial peptides form holes in cell membrane, as cytolysins do, particularly the single chain and single domain pore-forming toxin, like melittin. In addition to form pores, some antimicrobial peptides are able to enter into the cell by receptor-independent endocytosis, but this mechanism is restricted for a small number of 
peptides. In this particular respect, antimicrobial peptides and cell-penetrating peptide act in by the same way. Cell-penetrating peptides which are natural or synthetic, intact or fragments of larger polypeptides share structural properties with antimicrobial peptides. Initially, it was believed that CPPs might penetrate cell membrane by receptor-independent endocytosis, but cummulative data has indicated that they also gain access to the cell compartments by receptor-mediated endocytosis via endosome pathway or retrograde pathway to ER.

Since these classes of peptides and protein toxins have structures built by modular domains, in one case ('A' and ' $\mathrm{B}$ ' domains), or secondarily arranged $\alpha$-helices and $\beta$-sheets, in other, they can be engineered to convey biomolecules and nanoparticles into the cytoplasm of specific cell types, as well into the other cell compartments, like the nucleus. Therefore, their derivatives are being used for therapeutical and diagnostic purposes.

In conclusion, the research horizon of membranetranslocating peptides and toxins is so wide and bright that deserves all of our effort for finding better molecular scapels to dissect the cellular processes, as well as to generate better delivery system to transport drugs, genes, proteins and nanomaterials to specific target cells.

\section{Acknowledgments}

We are grateful to Fundação de Amparo à Pesquisa do Estado de São Paulo (FAPESP), São Paulo-SP, Brasil, and Conselho Nacional de Desenvolvimento Científico e Tecnológico (CNPq), Brasília-DF, Brasil, for the financial support.

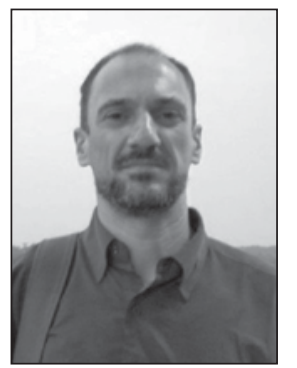

Gandhi Rádis Baptista - BS (1993) in Pharmacy and Biochemistry from University of São Paulo. Received his MSc in Technology of Fermentation in 1996, and his PhD in Life Sciences (Biochemistry) in 2002, both from University of São Paulo. He was associate researcher (postdoctoral fellow) in the Laboratory of Molecular Toxinology at Instituto Butantan (2002-2003). Participated of several scientific missions to the National Institute of Advanced Industrial Science and Technology (AIST/MITI), Japan. Presently, he is associate professor in Department of Biochemistry at Federal University of Pernambuco. His main scientific interests are polypeptides from terrestrial and marine organims, cell receptors, molecular interaction and recombinant DNA technology.

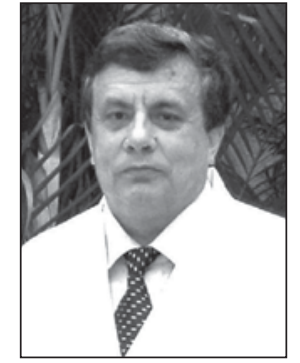

Alexandre Kerkis - BS (1968) and $\mathrm{MSc}$ in Citology and Genetics from Federal University of Novosibirsk (Russia). He received his PhD degree (1974) in Life Sciences (Cell differentiation) from Federal University of Sankt-Petersburg (Russia). He is full professor in the Institute of Citology and Genetics of Russian Academy of Science. Presently, he is the head of Laboratory of Stem Cells at the 'Centro de Pesquisa em Reprodução Humana Roger Abdelmassih' (São Paulo, Brazil). His main research interests are somatic cell hybrids, transgenic technology, gene therapy and stem cells.

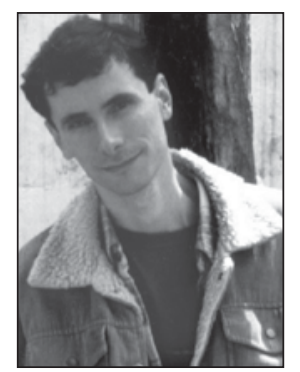

Álvaro Rossan de Brandão Prieto da Silva - He got his medical doctor degree in veterinary in 1991 from Veterinary Science and Medicine School at University of São Paulo. He received his PhD in Biochemistry and Molecular Biology from the same university in 2002. Today, he is scientific researcher in Laboratory of Herpetology at Instituto Butantan (São Paulo, Brazil). He is member of the Brazilian Society of Toxinology (SBTX) and the Brazilian Society of Biochemistry and Molecular Biology (SBBq). His research interests are three finger toxins, snake neurotoxins, animal toxins and structural and molecular biology.

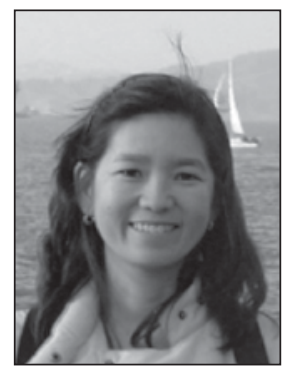

Mirian Akemi Furuie Hayashi $B S$ in Phamacy and Biochemistry (1987) from Universidade Estadual de Londrina (Paraná, Brazil). PhD in Life Sciences (Molecular Biology) from Federal University of São Paulo (1997). She worked as researcher in the department of drug development at Roche Pharmaceutics, Japan (1990-1992). Associate (1998-2003) and permanent researcher (2004-2006) in Instituto Butantan. Today, she is associate professor in Department of Pharmacology at Federal University of São Paulo. She is active collaborator in the Center of Applied Toxinology at Instituto Butantan (CAT/CEPID). Her main scientific interests are endopeptidases, oligopeptides, neuropeptides and animal toxins. 


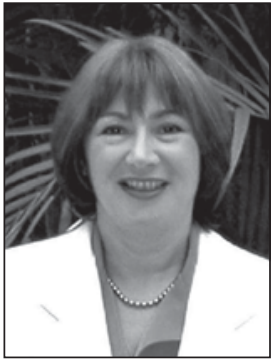

\section{Irina Kerkis}

$B S$ in Biology and Chemistry from Federal University of Tomsky (Russia) in 1978. MSc in Life Sciences in 1981 from the same University. Received her PhD in Life Sciences from the Institute of Citology and Genetics of Russian Academy of Sciences in 1989. She holds the title of full professor of Life Sciences from the Federal University of Novosibirsk (Russia) and, today, has a permanent position of scientific researcher in Department of Genetics at Instituto Butantan (São Paulo, Brazil). Her scientific interests are differentitation of stem cells, cell penetrating peptides, molecular diagnostic and Cell Biology.

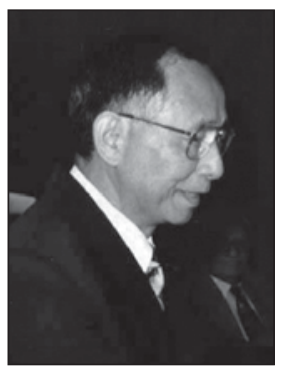

\section{Tetsuo Yamane}

$B S$ (1956) and PhD (1960) in Chemistry from California Institute of Technology (Caltech). Joined the Bell Laboratories, Murray Hill, $N J$, where he helped to establish the Department of Molecular Biophysics, working on application of spectroscopy for biological systems; developed the use of optical tweezers (laser) for manipulating cellular components. Returned to Brazil in 1994 and presently is at the Centro de Biotecnologia da Amazônia. He is a member of the Academia Brasileira de Ciências. Nowadays, his field of interest is principally related to Chemical Ecology.

\section{References}

1. Geny, B.; Popoff, M. R.; Biol. Cell. 2006, 98, 667.

2. Kaneko, J.; Kamio, Y.; Biosci. Biotechnol. Biochem. 2004, 68 , 981.

3. Cornut, I.; Buttner, K.; Dasseux, J. L.; Dufourcq, J.; FEBS Lett. 1994, 349, 29

4. Chen, F. Y.; Lee, M.T.; Huang, H. W.; Biophys. J. 2003, 84, 3751.

5. Pluzhnikov, K.; Nosyreva, E.; Shevchenko, L.; Kokoz, Y.; Schmalz, D.; Hucho, F.; Grishin, E.; Eur. J. Biochem. 1999, $262,501$.

6. Kristan, K.; Podlesek, Z.; Hojnik, V.; Gutierrez-Aguirre, I.; Guncar, G.; Turk, D.; Gonzalez-Manas, J. M.; Lakey, J. H.; Macek, P.; Anderluh, G.; J. Biol. Chem. 2004, 279, 46509.

7. Anderluh, G.; Macek, P.; Toxicon 2002, 40, 111.

8. Kuhn-Nentwig, L.; Cell. Mol. Life Sci. 2003, 60, 2651.

9. Barth, H.; Aktories, K.; Popoff, M. R.; Stiles, B. G.; Microbiol. Mol. Biol. Rev. 2004, 68, 373.
10. Lord, J. M.; Smith, D. C.; Roberts, L. M.; Cell. Microbiol. 1999 , 1,85 .

11. Falnes, P. O.; Sandvig, K.; Curr. Opin. Cell. Biol. 2000, 12, 407.

12. Sandvig, K.; van Deurs, B.; Annu. Rev. Cell. Dev. Biol. 2002, $18,1$.

13. Hartley, M. R.; Lord, J. M.; Biochem. Biophys. Acta 2004, 1701, 1.

14. Stirpe, F.; Battelli, M. G.; Cell. Mol. Life Sci. 2006, 63, 1850.

15. Kreitman, R. J.; AAPS J. 2006, 8, E532.

16. Pastan, I.; Hassan, R.; FitzGerald, D. J.; Kreitman, R. J.; Annu. Rev. Med. 2007, 58, 221.

17. Yang, Z. R.; Wang, H. F.; Zhao, J.; Peng, Y. Y.; Wang, J.; Guinn, B. A.; Huang, L. Q.; Cancer Gene Ther. 2007, 14, 599.

18. Goletz, T. J.; Klimpel, K. R.; Leppla, S. H.; Keith, J. M.; Berzofsky, J. A.; Hum. Immunol. 1997, 54, 129.

19. Gaur, R.; Gupta, P. K.; Goyal, A.; Wels, W.; Singh, Y.; Biochem. Biophys. Res. Commun. 2002, 297, 1121.

20. Spitznagel, J. K.; Methods Mol. Biol. 1997, 78, 1.

21. Fernandez de Caleya, R.; Gonzalez-Pascual, B.; Garcia-Olmedo, F.; Carbonero, P.; Appl. Microbiol. 1972, 23, 998.

22. Steiner, H.; Hultmark, D.; Engstrom, A.; Bennich, H.; Boman, H. G.; Nature 1981, 292, 246.

23. Zasloff, M.; Proc. Natl. Acad. Sci. U S A. 1987, 84, 5449.

24. Lehrer, R. I.; Ganz, T.; Selsted, M. E.; Cell 1991, 64, 229.

25. Andreu, D.; Rivas, L.; Biopolymers 1998, 47, 415.

26. Boman, H. G.; Scand. J. Immunol. 1998, 48, 15.

27. Tossi, A.; Sandri, L.; Curr. Pharm. Des. 2002, 8, 743.

28. Ganz, T.; Selsted, M. E.; Lehrer, R. I.; Eur. J. Haematol. 1990, 44,1 .

29. Bulet, P.; Stocklin, R.; Menin, L.; Immunol. Rev. 2004, 198, 169.

30. Zasloff, M.; Nature 2002, 415, 389.

31. Zasloff, M.; Nat. Med. 2006, 12, 607.

32. Parish, C. A.; Jiang, H.; Tokiwa, Y.; Berova, N.; Nakanishi, K.; McCabe, D.; Zuckerman, W.; Xia, M. M.; Gabay, J. E.; Bioorg. Med. Chem. 2001, 9, 377.

33. Hayes, M.; Ross, R. P.; Fitzgerald, G. F.; Hill, C.; Stanton, C.; Appl. Environ. Microbiol. 2006, 72, 2260.

34. Brogden, K. A.; Nat. Rev. Microbiol. 2005, 3, 238.

35. Kobayashi, S.; Chikushi, A.; Tougu, S.; Imura, Y.; Nishida, M.; Yano, Y.; Matsuzaki, K.; Biochemistry 2004, 43, 15610.

36. Tomasinsig, L.; Skerlavaj, B.; Papo, N.; Giabbai, B.; Shai, Y.; Zanetti, M.; J. Biol. Chem. 2006, 281, 383.

37. Powers, J. P.; Rozek, A.; Hancock, R. E.; Biochim. Biophys. Acta. 2004, 1698, 239.

38. Den Hertog, A. L.; Wong Fong Sang, H. W.; Kraayenhof, R.; Bolscher, J. G.; Van't Hof, W.; Veerman, E. C.; Nieuw Amerongen, A. V.; Biochem. J. 2004, 379, 665.

39. Kamysz, W.; Okroj, M.; Lukasiak, J.; Acta Biochim. Pol. 2003, 50,461 .

40. Cruz-Chamorro, L.; Puertollano, M. A.; Puertollano, E.; de Cienfuegos, G. A.; de Pablo M. A.; Peptides 2006, 27, 1201. 
41. Lehmann, J.; Retz, M.; Sidhu, S.S.; Suttmann, H.; Sell, M.; Paulsen, F.; Harder, J.; Unteregger, G.; Stockle, M.; Eur. Urol. 2006, 50, 141 .

42. Ramanathan, B.; Wu, H.; Ross, C. R.; Blecha, F.; Dev. Comp. Immunol. 2004, 28, 163.

43. Rivas, L.; Andreu, D.; Enferm. Infecc. Microbiol. Clin. 2003, 21,358 .

44. Frankel, A. D.; Pabo, C. O.; Cell 1988, 55, 1189.

45. Joliot, A.; Pernelle, C.; Deagostini-Bazin, H.; Prochiantz, A.; Proc. Natl. Acad. Sci. U S A. 1991, 88, 1864.

46. Derrossi, D.; Joliot, A. H.; Chassaing, G.; Prochaiantz, A.; J. Biol. Chem. 1994, 269, 10444.

47. Vivés, E.; Brodin, P.; Lebleu, B.; J. Biol. Chem. 1997, 272, 16010.

48. Futaki, S.; Int. J. Pharm. 2002, 245,1.

49. Kabouridis, P. S.; Trends Biotechnol. 2003, 21, 498.

50. Langel, U.; Drug Discov. Today 2004, 9, 395.

51. Joliot, A.; Sci. STKE. 2005, 313, 54.

52. Ferrari, A.; Pellegrini, V.; Arcangeli, C.; Fittipaldi, A.; Giacca, M.; Beltram, F.; Mol. Ther. 2003, 8, 284.

53. Fittipaldi, A.; Ferrari, A.; Zoppe, M.; Arcangeli, C.; Pellegrini, V.; Beltram, F.; and Giacca, M.; J. Biol. Chem. 2003, 36, 34141 .

54. Vendeville, A.; Rayne, F.; Bonhoure, A.; Bettache, N.; Montcourrier, P.; Beaumelle, B.; Mol. Biol. Cell 2004, 15, 2347.

55. Wadia, J. S.; Stan, R. V.; Dowdy, S. F.; Nat. Med. 2004, 10, 310.

56. Jones, S. W.; Christison, R.; Bundell, K.; Voyce, C. J.; Brockbank, S. M.; Newham, P.; Lindsay, M. A.; Br. J. Pharmacol. 2005, 145, 1093.

57. Ford, K. G.; Darling, D.; Souberbielle, B.; Farzaneh, F.; Mech. Ageing. Dev. 2000, 121, 113.

58. Elliott, G.; O’Hare, P.; Cell 1997, 88, 223.

59. Nagahara, H.; Vocero-Akbani, A.; Snyder, E.; Ho, A.; Latham, D.; Lissy, N.; Becker-Hapak, M.; Ezhevsky, S.; Dowdy, S.; Nat. Med. 1998, 4, 1449.

60. Phelan, A.; Elliott, G.; O’Hare, P.; Nat. Biotech. 1998, 16, 440.

61. Dilber, M.; Phelan, A.; Aints, A.; Mohamed, A.; Elliott, G.; Edvard Smith, C.; O'Hare, P.; Gene Ther. 1999, 6, 12.

62. Cashman, S. M.; Sadowski, S. L.; Morris, D. J.; Frederick, J.; Kumar-Singh, R.; Mol. Ther. 2002, 6, 813.

63. Zhao, M.; Weissleder, R.; Med. Res. Rev. 2004, 24, 1.

64. Chuah, M. K.; Collen, D.; Vanden-Driessche, T.; Curr. Gene Ther. 2003, 3, 527 .
65. Mehier-Humbert, S.; Guy, R. H.; Adv. Drug. Deliv. Rev. 2005, $57,733$.

66. Kerkis, A.; Kerkis, I.; Rádis-Baptista, G.; Oliveira, E. B.; Vianna-Morgante, A. M.; Pereira, L. V.; Yamane, T.; FASEB J. 2004, 18, 1407.

67. Nascimento, F. D.; Hayashi, M. A.; Kerkis, A.; Oliveira, V.; Oliveira, E. B.; Radis-Baptista, G.; Nader, H. B.; Yamane, T.; Tersariol, I. L.; Kerkis, I.; J. Biol. Chem. 2007, 282, 21349.

68. Lundberg, P.; El-Andaloussi, S.; Sutlu, T.; Johansson, H.; Langel. U.; FASEB J. 2007, 21, 2664.

69. Melikov, K.; Chernomordik, L. V.; Cell. Mol. Life Sci. 2005, $62,2739$.

70. Gonçalves, J. M.; Vieira., L. G.; An. Acad. Bras. Cienc. 1950, $22,141$.

71. Nicastro, G.; Franzoni, L.; Chiara, C.; Mancin, A. C.; Giglio, J. R.; Spisni, A.; Eur. J. Biochem. 2003, 270, 1969.

72. Fadel. V.; Bettendorff, P.; Herrmann, T.; de Azevedo Jr., W. F.; Oliveira, E. B.; Yamane, T.; Würthrich, K.; Toxicon 2005, 46, 759.

73. Mouhat. S.; Jouirou, B.; Mosbah, A.; De Waard, M.; Sabatier, J. M.; Biochem. J. 2004, 378, 717.

74. Boisseau, S.; Mabrouk, K.; Ram, N.; Garmy, N.; Collin, V.; Tadmouri, A.; Mikati, M.; Sabatier, J. M.; Ronjat, M.; Fantini, J.; De Waard, M.; Biochim. Biophys. Acta 2006, 1758, 308.

75. Takeshima, K.; Chikushi, A.; Lee, K. K.; Yonehara, S.; Matsuzaki, K.; J. Biol. Chem. 2003, 278, 1310.

76. Henriques, S. T.; Melo, M. N.; Castanho, M. A.; Mol. Membr. Biol. 2007, 24, 173.

77. Patel, L. N.; Zaro, J. L.; Shen, W. C.; Pharm. Res. 2007, 24, 1977.

78. Henriques, S. T.; Melo, M. N.; Castanho, M. A.; Biochem. J. 2006, 399, 1.

79. Mae, M.; Langel, U.; Curr. Opin. Pharmacol. 2006, 6, 509.

80. Gupta, B.; Levchenko, T. S.; Torchilin, V. P.; Adv. Drug Deliv. Rev. 2005, 57, 637.

81. Harada, H.; Kizaka-Kondoh, S.; Hiraoka, M.; Breast Cancer 2006, 13, 16.

82. Su, W.; Mishra, R.; Pfeuffer, J.; Wiesmuller, K. H.; Ugurbil, K.; Engelmann, J.; Contrast Media Mol. Imaging 2007, 2, 42.

Received: August 21, 2007 Published on the web: February 29, 2008

FAPESP helped in meeting the publication costs of this article. 